\title{
Isolation of entomopathogenic nematodes in an apple orchard in Southern Brazil and its virulence to Anastrepha fraterculus (Diptera: Tephritidae) larvae, under laboratory conditions
}

\author{
E. Foelkel ${ }^{a *}$, M. Voss $^{b}$, L. B. Monteiro ${ }^{a}$ and G. Nishimura ${ }^{a}$ \\ ${ }^{a}$ Laboratório de Manejo Integrado de Pragas - LAMIP, Departamento de Fitotecnia e Fitossanitarismo, \\ Universidade Federal do Paraná - UFPR, Rua dos Funcionários, 1540, CEP 80035-050, Curitiba, PR, Brazil

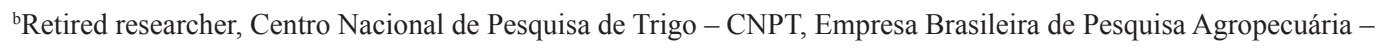 \\ Embrapa Trigo, Rua Brazilio de Araújo, 341, CEP 81312-050, Curitiba, PR, Brazil \\ *e-mail: ester.foelkel@eucalyptus.com.br
}

Received: May 26, 2015 - Accepted: November 2, 2015 - Distributed: February 28, 2017

(With 3 figures)

\begin{abstract}
Entomopathogenic nematodes (EPNs) are a promising alternative to integrated control in many fruit pests. Few studies were made on the relationship of Anastrepha fraterculus natural population with native EPNs population and other biotic and abiotic factors. The aim of this work was to verify the occurrence of endemic nematodes in an apple orchard, concerning environmental conditions and technical procedure, and access isolates virulence to A. fraterculus larvae. The experiment was conducted during a year taking monthly soil samples from an apple orchard, with and without fallen fruits just above the soil. Samples were baited with Tenebrium molitor and A. fraterculus larvae in laboratory. Canopy and fallen fruits were sampled to access the pest infestation. Seventy three EPN isolates were captured, in $23.2 \%$ soil samples, more with $T$. molitor than with $A$. fraterculus baits. From the 20 isolates tested against $A$. fraterculus, only five were pathogenic, and they were identified as Oscheius sp. The nematodes were captured during all seasons in a similar frequency. Soil and weather conditions, presence of fruit over the orchard soil, and A. fraterculus pupae in the fruits had no significant influence on the capture. As a conclusion, nematodes of the genera Oscheius are found in an apple orchard of Porto Amazonas constantly along the year, independently of fluctuations in A. fraterculus population, climate conditions and presence of fruit over the soil. Some of the isolates are pathogenic to A. fraterculus.
\end{abstract}

Keywords: South-American fruit fly, biological control, Oscheius, EPN, Malus domestica.

\section{Isolamento de nematoides entomopatogênicos em pomar de macieira no sul do Brasil e virulência em larvas de Anastrepha fraterculus (Diptera: Tephritidae) em condições de laboratório}

\begin{abstract}
Resumo
Nematoides entomopatogênicos (NEPs) são alternativa promissora para o controle integrado de várias pragas de frutíferas. Foram feitos poucos estudos ecológicos sobre a relação de populações naturais de Anastrepha fraterculus com a de NEPs nativos e outros fatores bióticos e abióticos. O objetivo desse trabalho foi verificar a ocorrência de nematoides endêmicos de um pomar de macieira, considerando condições ambientais e procedimentos técnicos, e testar a virulência de isolados para larvas de $A$. fraterculus. $\mathrm{O}$ experimento foi conduzido durante um ano coletando mensalmente amostras de solo de um pomar de macieira com e sem frutos acima do solo. Foram feitas armadilhas com larvas de Tenebrium molitor e de A. fraterculus em laboratório. Frutos na copa e caídos no solo foram amostrados para quantificar a infestação da praga. Setenta e três isolados de NEPs foram capturados em $23,2 \%$ das amostras de solo, mais em armadilhas de T. molitor do que em A. fraterculus. Dos 20 isolados testados contra A. fraterculus, apenas cinco foram patogênicos, e eles foram identificados como Oscheius sp. Os nematoides foram capturados durante todas as estações e em frequência similar. Condições edáficas e climáticas, presença do fruto acima do solo amostrado e de pupas de $A$. fraterculus nos frutos não tiveram influência significativa na captura. Como conclusão, nematoides do gênero Oscheius ocorrem em pomar de macieira de Porto Amazonas de forma constante ao longo do ano, independentemente de flutuações na população de $A$. fraterculus, condições climáticas e presença de fruto sobre a superfície do solo. Alguns isolados são patogênicos para A. fraterculus.
\end{abstract}

Palavras-chave: moscas-da-fruta-sulamericana, controle biológico, Oscheius, NEP, Malus domestica. 


\section{Introduction}

South-American fruit fly, Anastrepha fraterculus (Wied.) (Diptera: Tephritidae), has a wide distribution in America and can be found in almost all parts of South America. In southern Brazil, the species domains and can harm at least 67 hosts, including the exotic ones like apple (Malus domestica Borkh.) (Zucchi, 2000a). In laboratory condition, the adult can survive six months and the female is able to lay more than 400 eggs during lifetime (Salles, 2000). The larvae feed on fruit pulp and induce its earlier ripening and falling (Souza-Filho et al., 2009). On soil, late third-instar larva leaves the fruit and turns to pupa nearby into the soil. Last larval instar and pupal phase takes 15 days at $25^{\circ} \mathrm{C}$ (Salles, 2000) and this is the suitable time for many soil biocontrolers to infect $A$. fraterculus (Rodrigues-Trentini, 1996).

Entomopathogenic nematodes (EPNs) are having promising results on biological control and are an alternative measure for many soil pests control (Stock, 2005). There are three different genus mostly known as EPNs: Steinernema, Heterorhabiditis and Neosteinernema. They are entomopathogenic bacteria vectors (Poinar-Junior, 1990). More recently the genus Oscheius was discovered as EPN (Torres-Barragan et al., 2011). There are few studies on demonstrating Oscheius contribution to biological control, since most species of this genus have facultative-parasite habit (Ye et al., 2011). Oscheius sp. have symbiotic relationship with entomopathogenic bacteria, caring them not inside its body like obligate EPNs do, but in its body surface. When bacteria are present, Osheius sp. are able to infect and kill insect species (Torres-Barragan et al., 2011), but they were not reported infecting $A$. fraterculus yet. In this work, for convenience, all isolated are called EPN, including Oscheius. EPNs have been studied as biocontrolers candidate of several fruit flies species (Lezama-Gutiérrez et al., 2006; Barbosa-Negrisoli et al., 2009; Rohde et al., 2012; Toledo et al., 2014). However, few studies at orchard condition were found in the literature and even less works reporting EPNs natural occurrence. In a Florida citrus orchard, the increase on EPN population was correlated only with soil temperature (Beavers et al., 1983). McGraw and Koppenhöfer (2009) found a positive correlation between the increase of native EPNs population and the host Listronotus maculicollis Kirby (Coleoptera: Curculionidae) in turfgrass.

The aim of this work was to verify the occurrence of isolate endemic entomopathogenic nematodes strains, characterize their seasonality and relation with biotic and abiotic factors in an apple orchard of Porto Amazonas, PR, Brazil, and select strains capable of infect and kill A. fraterculus in laboratory conditions.

\section{Material and Methods}

\subsection{Orchard soil samples and EPN capture}

An apple orchard (cultivar Eva), in Porto Amazonas, Paraná, Brazil (25³2'08'S 4954'52'W, 865-m high, climate $\mathrm{Cfb}$ - Köppen) divided in six $100-\mathrm{m}^{2}$ sectors was sampled. Samples were taken away and under fallen apples, following Voss et al. (2009). From July 7 to September 19, 2013 (dates at Figure 1A), two sectors were sampled (total of 18 samples each date). From October 17, 2013, to August 8, 2014, all six sectors were sampled (total of 24 samples each date). In laboratory, $25 \pm 2{ }^{\circ} \mathrm{C}$ and natural photophase and relative humidity, samples were baited with five late-instar Tenebrium molitor L. (Coleoptera: Tenebrionidae) in a 500-mL plastic pot (Voss et al., 2009), and alternative baits were made with $A$. fraterculus larvae in smaller pots (50-mL, because $A$. fraterculus is less mobile) sealed with parafilm. Dead insects with EPN symptoms were placed in White traps, kept at $24 \pm 1{ }^{\circ} \mathrm{C}$, dark and $70 \pm 10 \%$ relative humidity (Voss et al, 2009). The infective (dauer larvae) juveniles (IJ) were recovered every two days, purified and placed in tissue culture bottles. Isolates were tested for entomopathogenicity, and multiplied, in late-instar Galleria mellonella L. (Lepidoptera: Pyralidae) as Rio and Cameron (2000). The isolates were identified by a numeric code following the soil sample order. EPN stock samples were kept at $15^{\circ} \mathrm{C}$ (Barbosa-Negrisoli et al., 2009).

\subsection{Monitoring environmental condition and Anastrepha sp. population}

Data on temperature in Lapa County (closer available data) and rainfall in Porto Amazonas were provided by Simepar (Sistema Meteorológico do Paraná, Brazil) (Figure 2). Physical and chemical soil characteristics were accessed for each sector by specialized laboratories. The soil is a Haplic Cambisol, loam in four orchard sectors (42.25\% sand, $24.25 \%$ clay, $33.25 \%$ silt, $4.78 \%$ O.M., $450.9 \mathrm{mg} / \mathrm{dm}^{3} \mathrm{~K}, 71.28 \mathrm{mg} / \mathrm{dm}^{3} \mathrm{P}, 2.92 \mathrm{cmol}_{\mathrm{c}} / \mathrm{dm}^{3} \mathrm{Mg}$, $\left.13.13 \mathrm{cmol}_{\mathrm{c}} / \mathrm{dm}^{3} \mathrm{Ca}, 6.38 \mathrm{pH}\right)$ and sandy loam in the other two sectors ( $45.5 \%$ sand, $12.5 \%$ clay, $42 \%$ silt, $4.5 \%$ O.M., $435.6 \mathrm{mg} / \mathrm{dm}^{3} \mathrm{~K}, 194.3 \mathrm{mg} / \mathrm{dm}^{3} \mathrm{P}, 2.6 \mathrm{cmol}_{\mathrm{c}} / \mathrm{dm}^{3} \mathrm{Mg}$, $\left.16 \mathrm{cmol}_{\mathrm{c}} / \mathrm{dm}^{3} \mathrm{Ca}, 6.6 \mathrm{pH}\right)$.

The relationship of the proportion of EPN-positive samples with clay, sand and organic matter soil content, precipitation cumulated and mean air temperature two until six days before sampling, was analyzed through Spearman correlation.

Anastrepha fraterculus population fluctuation was determined by monitoring fruit fly apple infestation. Fruit samples were collected from July 11, 2013 to July 03, 2014. Samples from each sector were composed by twenty fruits (from four plants of a row) every week during harvest season and six fruit (from three plants) biweekly after and before harvest. Fallen fruit were sampled the same way when available. In laboratory, fruit were laid on vermiculite according to Nascimento et al. (2000). Pupae were placed in Petri dishes with filter paper and moist with distilled water until fly emergency. Two days after emergency, flies were registered and stored in ethanol $70 \%$ to identification (Nascimento et al., 2000; Zucchi, 2000b; Marsaro Júnior et al., 2013).

The relationship of the proportion of EPN-positive samples with $A$. fraterculus pupae was analyzed through Spearman correlation. The proportions of EPN-positive 

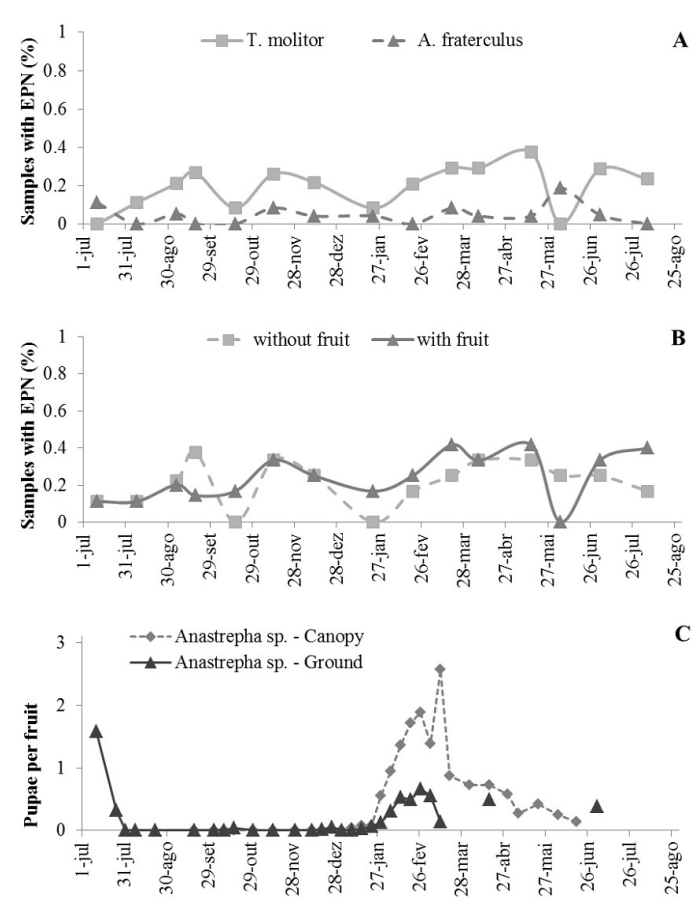

Figure 1. Relative frequency of EPNs - positive soil samples when the bait was Tenebrio molitor or Anastrepha fraterculus larvae (A), and when samples were collected without or with an apple over the soil (B). In chart (C) the number of Anastrepha sp. pupae obtained from apples collected in the canopies or orchard ground. Time is about one 'Eva' apple production cycle in Porto Amazonas, PR.
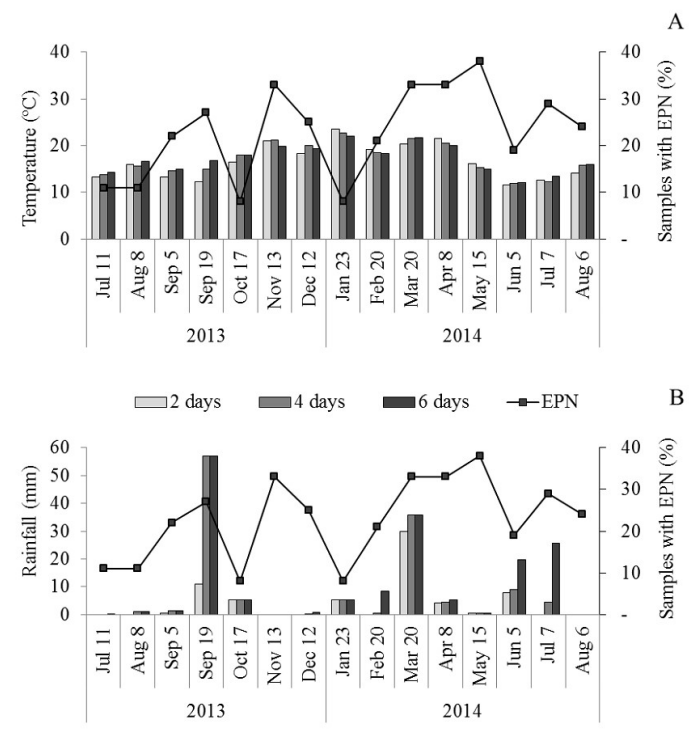

Figure 2. Mean air temperature measured in Lapa- PR (A) and rainfall cumulated in Porto Amazonas- PR (B), 2, 4 and 6 days before soil sampling (sampling day included) from Jul 11, 2013 to Aug 6, 2014, and percentage of samples with entomopathogenic nematode (EPN) captured (right axis) in soil from an apple orchard in Porto Amazonas. Weather data provided by Simepar. samples in the subsets with and without fruit upon the sample site were compared by chi-square tests. The software BIOESTAT 5.0 was used to both tests (Ayres et al., 2007). Additionally, data on EPN capture were split by season and the proportion on EPN-positive samples was compared through a chi-square test (Campbell et al., 1995).

\subsection{Virulence to A. fraterculus}

An A. fraterculus population from Cena (Centro de Energia Nuclear na Agricultura, Piracicaba - Brazil), was reared following Walder et al. (2014) to obtain late third-instar larvae. They were used in an experiment completely random designed, with five repetitions composed by a nine-centimeter Petri dishes (Rohde et al., 2012) with 12 larvae, in a dark climatic chamber $\left(24 \pm 2{ }^{\circ} \mathrm{C}\right.$, U.R. $70 \pm 10 \%$ ). Twenty nematode isolates from Porto Amazonas apple orchard, pathogenic to G. mellonella, were tested split in three trials, each one including a negative control (distilled water) and a positive control with Steinernema carpocapsae CB 02 (provided by Instituto Biológico de Campinas), multiplied as in Voss et al. (2009). The IJ concentration was determined by counting 20 -microliter drops with five replicates, using an optical microscope (Voss et al., 2009). Each larva (except in water control) was treated with 100 IJ (Barbosa-Negrisoli et al., 2009) suspended in $0.6 \mathrm{~mL}$ distilled water. The number of flies emerged was registered twenty five days after inoculation. Dead insects were dissected under amplification for confirmation of infection by nematode (Barbosa-Negrisoli et al., 2009). The control efficiency was calculated according to Abbott (1925). Data were square-root transformed to reach normality and submitted to analysis of variance and Tukey test using R 3.02 (R Development Core Team, 2008).

\subsection{Isolates identification}

Five isolates were selected based on its virulence to A. fraterculus and sent to identification by Dr. Tesfamariam Mengistu at Florida University. DNA was extracted from five first generation female nematodes from each isolate placed in 1.5-mL Eppendorf tubes each containing $20 \mu 10.25 \mathrm{M} \mathrm{NaOH}$ and incubated at $25{ }^{\circ} \mathrm{C}$ overnight (Floyd et al., 2002). Thereafter, samples were incubated at $99{ }^{\circ} \mathrm{C}$ for tree minutes and allowed to cool to room temperature, and then $4 \mu \mathrm{l} 0.25 \mathrm{M} \mathrm{HCl}, 10 \mu \mathrm{l} 0.5 \mathrm{M}$ Tris-HCl, $(\mathrm{pH} 8.0)$, and $5 \mu \mathrm{l}$ $2 \%$ Triton X-100 were added to each tube. Samples were vortexed, spun down, incubated at $99{ }^{\circ} \mathrm{C}$ for tree minutes, cooled to room temperature, and stored at $-20{ }^{\circ} \mathrm{C}$ until further use. ITS-rRNA gene was amplified using the ITS primers TW81 (5'-GTTTCCGTAGGTGAACCTGC-3') and AB28 (5'-ATATGCTTAAGTTCAGCGGGT-3') (Subbotin et al., 2001) by PCR in an Applied Biosystems 2720 Thermocycler (MJ Research, Waltham, MA, USA). The PCR conditions were: denaturation at $94{ }^{\circ} \mathrm{C}$ for five minutes; followed by 35 cycles of $94{ }^{\circ} \mathrm{C}$ for one minute, $52{ }^{\circ} \mathrm{C}$ for one minute, and $72{ }^{\circ} \mathrm{C}$ for one minute; and a final extension at $72{ }^{\circ} \mathrm{C}$ for 10 minutes. Eight microliters of the amplification product was electrophoresed on a $1.8 \%$ agarose gel and stained with ethidium bromide. 
The sizes of amplified products were determined by comparison with a $1 \mathrm{~kb}$ molecular weight ladder (Invitrogen). For direct sequencing, PCR products were purified with the QIA quick PCR purification kit (Qiagen) and sequenced. DNA sequences were compared to sequences from the GenBank National Centre for Biotechnology Information (NCBI) using BLAST search with standard algorithm parameters (NCBI, 2015).

\section{Results}

\subsection{EPN capture}

Seventy eight pathogenic isolates were captured from a total of 315 soil samples. Seventy tree samples were positive for EPN (23.2\%), because some samples were positive in both the trap types. The baits with T. molitor captured more EPNs than the ones with $A$. fraterculus (Chi-square test, $\mathrm{p}<0.05$ ) (Figure 1A). EPNs were captured in $63 \%$ T. molitor baits against $15 \%$ with $A$. fraterculus.

EPN-positive samples without fruit over the soil were $21 \%$ of the total against $25.7 \%$ with some fruit (Figure 1B). The difference was not significant (Chi-square test, $\mathrm{p}=0.39$ ). Furthermore, there was no significant correlation between the number of $A$. fraterculus pupae in the fruits of the sector and the proportion of positive samples $(r=0.52 ; \mathrm{p}=0.09)$ (Figure 1C). Ninety one percent of the pupae emerged from fruits gave rise to Anastrepha sp. and, among them, all females were A. fraterculus. In the same way, the proportion of EPN-positive samples among the year seasons was not significantly different (Chi-square test, $\mathrm{p}=0.36$ ), besides the differences in air temperature which fell during winter to $16-12^{\circ} \mathrm{C}$ (Figure 2A).

The correlation between cumulated rainfall two to six days before sampling and the proportion of EPN-positive samples was not significant $(r=-0.01 ; p=0.96)$. Some rain happened in the six days preceding soil collection in almost all evaluations (Figure 2B). No rain occurred before the sampling in November 2013 and August 2014 and EPNs were captured as well.

There was no correlation between sand or clay content and proportion of EPN positive samples $(\mathrm{r}=0.26, \mathrm{p}=0.62$ and $\mathrm{r}=-0.8, \mathrm{p}=0.10$, respectively). In the same way, no correlation was observed between soil organic matter content and the proportion of EPN positive sample $(\mathrm{r}=-0.39, \mathrm{p}=0.27)$.

\subsection{Virulence against $A$. fraterculus and isolates identification}

Among 20 isolates tested, native from Porto Amazonas apple orchard soil, five caused significantly higher mortality of A. fraterculus larvae than the control without nematode: 158 , 222, 288, 304 and 319 (Figure 3). Isolates 304 and 319 scored virulence of 73 and $71 \%$, respectively (Figure 3B). For the other tree pathogenic isolates, A. fraterculus mortality ranged from 33 to $54 \%$, also differing from the control (Figure $3 \mathrm{~A}$ and $3 \mathrm{C}$ ). Among the five pathogenic isolates, two (158 and 288) had significantly worse results on attacking A. fraterculus larvae than S. carpocapsae CB 02, which killed all the larvae exposed.

DNA amplification for the five isolates pathogenic to A. fraterculus with the primers TW81 and AB28 produced

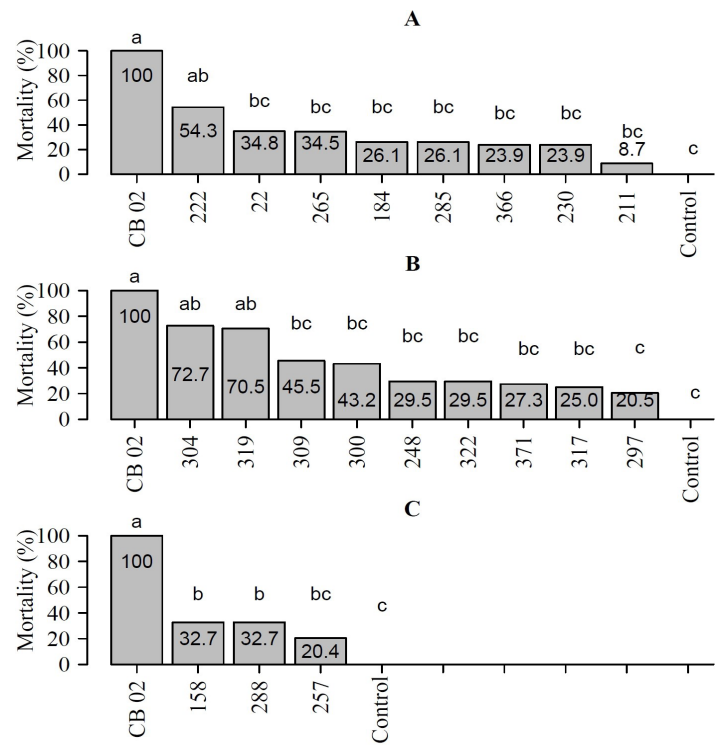

Figure 3. Mortality of Anastrepha fraterculus larvae following inoculation of different nematode strains isolated from soil in Porto Amazonas, PR, and Steinernema carpocapsae $\mathrm{CB}$ 02, in three trials performed in Petri dishes (100 IJ.larva ${ }^{-1}$ ) (A, B and C). Mortality was transformed by square root for statistical analysis, resulting in coefficient of variation $9.58,8.75$ and 6.26 for $\mathrm{A}, \mathrm{B}$ and $\mathrm{C}$, respectively; columns with the same letter above are not different (Tukey test, $\alpha=0.05$ ).

sequences ranging from 802 to 820 base pars. When compared to the gene bank, the isolate 222 showed $88 \%$ identity with Oscheius sp. isolate TEL-2014 (accession number KM492926.1) and $85 \%$ with Oscheius sp. isolate MCB (accession number KF684370.1) (Table 1). All the other isolates showed higher identity (98\%) with Oscheius sp. isolate MCB (accession number KF684370.1), with null e-values (Table 1).

\section{Discussion}

Tenebrio molitor baits captured significantly more EPN than A. fraterculus ones. This difference is probably due to the bigger soil volume in T. molitor baits. Besides, T. molitor moves inside the soil, which made the infection more likely. The proportion of EPN-positive samples obtained was considered low, when compared with other works using $G$. mellonella as bait: samples with nematodes reached 50\% (Rio and Cameron, 2000); Campbell et al. (1995) found nematode-positive soil samples between 25 and $38 \%$. Besides the possible difference in EPN density in the soils, for most EPNs G. mellonella is better than T. molitor because of its higher susceptibility and body size (Boff et al., 2000), what can explain at least partially the lower frequency observed here.

The presence of a fallen fruit over the soil is expected to increase arthropods abundance nearby, because of fruit fly larvae and pupae came from the fruit (Salles, 2000) and other insect species that feeds on the decomposing fruit are stimulated. These arthropods are possible hosts for EPNs. 
Table 1. Scores of identity (\%) and e-values (e) output in the comparisons of DNA sequences of eight accessions available at NCBI nucleotide data bank (NCBI, 2015) with sequences found in five nematode isolates from Porto Amazonas, PR.

\begin{tabular}{|c|c|c|c|c|c|c|c|c|c|c|}
\hline \multirow{3}{*}{ Accession $^{1}$} & \multicolumn{10}{|c|}{ Porto Amazonas' isolates } \\
\hline & \multicolumn{2}{|c|}{158} & \multicolumn{2}{|c|}{222} & \multicolumn{2}{|c|}{288} & \multicolumn{2}{|c|}{304} & \multicolumn{2}{|c|}{319} \\
\hline & $\%$ & $\mathbf{e}$ & $\%$ & e & $\%$ & $\mathbf{e}$ & $\%$ & $\mathbf{e}$ & $\%$ & $\mathrm{e}$ \\
\hline KF684370.1 & 98 & 0.0 & 85 & 0.0 & 98 & 0.0 & 98 & 0.0 & 98 & 0.0 \\
\hline KM492926.1 & 84 & 0.0 & 88 & 0.0 & 84 & 0.0 & 84 & 0.0 & 84 & 0.0 \\
\hline KF500235.1 & 85 & $1 \mathrm{e}^{-100}$ & 89 & $3 \mathrm{e}^{-92}$ & 85 & $1 \mathrm{e}^{-100}$ & 85 & $1 \mathrm{e}^{-100}$ & 85 & $1 \mathrm{e}^{-100}$ \\
\hline EF503690.1 & 85 & $2 \mathrm{e}^{-99}$ & 89 & $3 \mathrm{e}^{-92}$ & 85 & $2 \mathrm{e}^{-99}$ & 85 & $2 \mathrm{e}^{-99}$ & 85 & $2 \mathrm{e}^{-99}$ \\
\hline EU273598.1 & 85 & $7 \mathrm{e}^{-98}$ & 89 & $1 \mathrm{e}^{-90}$ & 85 & $7 e^{-98}$ & 85 & $7 e^{-98}$ & 85 & $8 \mathrm{e}^{-98}$ \\
\hline JQ002565.1 & 85 & $3 e^{-96}$ & 89 & $1 \mathrm{e}^{-90}$ & 85 & $3 e^{-96}$ & 85 & $3 e^{-96}$ & 85 & $4 e^{-96}$ \\
\hline FJ547241.1 & 89 & $4 e^{-66}$ & 90 & $1 \mathrm{e}^{-70}$ & 89 & $4 e^{-66}$ & 89 & $4 e^{-66}$ & 89 & $4 e^{-66}$ \\
\hline AM398825.1 & 81 & $8 \mathrm{e}^{-53}$ & 87 & $8 \mathrm{e}^{-53}$ & 81 & $8 \mathrm{e}^{-53}$ & 81 & $8 \mathrm{e}^{-53}$ & 81 & $8 \mathrm{e}^{-53}$ \\
\hline
\end{tabular}

${ }^{1}$ KF684370.1| Oscheius sp. MCB; KM492926.1| Oscheius sp. TEL-2014; KF500235.1| Heterorhabditidoides chongmingensis isolate FUMN101; EF503690.1| Heterorhabditidoides chongmingensis; EU273598.1| Rhabditis sp. Tumian-2007; JQ002565.1 Heterorhabditidoides sp. RG081015 ; FJ547241.1| Oscheius carolinensis; AM398825.1| Pellioditis mediterranea.

So, it was expected an increase in EPN capture when soil samples is taken underneath a fallen apple, but it was not observed here (Figure 1B), despite fruit infestation by A. fraterculus (Figure 1C). This trial didn't regard the total host range in the apple orchard, so the nematodes could have other suitable host or food source, even because $A$. fraterculus is not present during the entire year. Furthermore, a great number of arthropods live in orchards and are possible nematode hosts during all seasons, regardless fallen fruit (Glazer et al., 1996).

EPN-positive samples were not different across year seasons. Temperatures between $16-10{ }^{\circ} \mathrm{C}$ as observed in Porto Amazonas during winter usually reduces EPN efficacy (Klein, 1990; Mejia-Torres and Sáenz, 2013). However, winter temperatures seemed to be high enough to assure nematode capture during the entire year, even because samples were kept at $25^{\circ} \mathrm{C}$ in the laboratory, what favored the infection. The homogeneous occurrence of EPNs along the year corroborates Campbell et al. (1995) findings on Heterorhabditis sp. constancy during all seasons, and Puza and Mracek (2005) on Steinernema affine (Gerdin and Beddind). The capture of EPNs over different seasons, and recoveries in the same area during and after winter, indicates its population is well established.

Soil moisture is one of the most critical factors on nematodes movement and survival (Kaya, 1990), as observed in a Citrus sp. grove where higher humidity close to the roots was responsible by higher number of EPN-positive soil samples (Glazer et al., 1996). However, in the present work there was no correlation between rainfall and the proportion of samples with EPN captured, probably because sample soil humidity was corrected in laboratory (Voss et al., 2009), so this influence could have been diminished. It's prudent to have in mind that between-work differences could be related to the species considered. However, results for Oscheius sp. are still few or inexistent.

Different textures of soil didn't affect the capture of nematodes. It was expected that sandy soil could have more EPNs captured, especially because of the pore sizes that enhance nematode efficiency (Kaya, 1990). Hoy et al. (2008) observed that Rhabditis sp. bacteria feeders were found in most vegetable cultivated soil, beside the differences in sand content from 29.7 to $49.1 \%$. In the same way, organic matter was not an important factor in EPN capture. Organic matter richer soils have more microorganism activity, which means more food sources for facultative EPNs like Oscheius. Bacterial activity in the soil correlated positively with number of the facultative-EPN Rhabditis sp. collected (Hoy et al., 2008). The soil collected in this trial was rich in organic matter $(3.8-5 \%)$ what can be enough to ensure good microorganism activity.

Five isolates from this trial were found to be close related to two accessions of Oscheius sp. (MCB and TEL-2014). Besides other accessions were found to be more identical to isolate 222, e-values for TEL-2014 and MCB pairing were lower $(0.0)$, because the query cover was higher. The smaller the e-value, the higher the chance of matches not to be random, but due to relativeness. The accession MCB was already supported as entomopathogenic (Serepa and Gray, 2014). The isolate Oscheius sp. TEL-2014 was collected in a loam sandy soil on $G$. mellonella baits in South Africa (NCBI, 2015).

In South America, some Oscheius species [Oscheius colombiana and Rhabditis (Oscheius) pheropsophi n. sp.] were already found associated with insect in Colombia and southeast Brazil, respectively (Smart and Nguyen, 1994; Stock et al., 2005). However, it is possible that the captured isolates are new species since there is no report of this genus in south Brazil. The identification of these new facultative insect-parasitic nematodes is important since they can be natural pest enemies, and also can help on equilibrating soil insect populations. Further studies are necessary on the species-level identification, morphometric characteristics, associated bacteria identification and the relationship between them, involving biotic and abiotic factors.

It was observed differences in virulence to $A$. fraterculus between 304 and 297 as well as 319 and 297 (Figure 3B). Assuming the isolates are the same species (if not, it would explain the differences), the difference in virulence can be explained by the kind and amount of bacteria each 
isolate carries. In Oscheius sp., the association between nematode and bacteria is symbiotic, not mutualistic as in Heterorhabiditis and Steinernema genera. Although the associated bacterium was not studied in this work, it is known that Oscheius-associated bacterium doesn't live inside its body, but on its surface (Torres-Barragan et al., 2011). Four different bacteria species were associated with Rhabditis (Oscheius) blumi Sabhaus. Only two were pathogenic to G. mellonella and with different virulence (Park et al., 2011). So, it is likely to be similar in the isolates captured here. Still, Oscheius sp. isolates which were less virulent to A. fraterculus can have other suitable food source at field since they have facultative-parasitic behavior.

It was expected that EPNs captured in the orchard would be more virulent to the same orchard pest $A$. fraterculus than $S$. carpocapsae CB 02, which was cllected in Florida (USA). However, it didn't happen. Similar observation was already reported in other insects (Grewal et al., 2002). Rodrigues-Trentini (1996) also found high virulence of $S$. carpocapsae to A. fraterculus larvae. Steinernema carpocapsae is an obligate parasite, with a wide range of hosts, and needs to be highly effective to survive, while Oscheius sp., as explained above, can feed in sources other than live insects.

As a conclusion, nematodes of the genera Oscheius are found in an apple orchard of Porto Amazonas. Some of them are pathogenic to Anastrepha fraterculus. Facultative EPNs population is constant along the year in the orchard, independently of fluctuations in A. fraterculus population, air temperature, pluvial precipitation and presence of fruit over the soil surface.

\section{Acknowledgements}

This work was supported by the Conselho Nacional de Desenvolvimento Científico e Tecnológico (CNPq). We thank Edson Chappuis by the help with the insect rearing, Maria de Lourdes Zamboni Costa, from CENA, and Luis Garrigós Leite, from Instituto Biológico de Campinas, by the provision of biological material.

\section{References}

ABBOTT, W.S., 1925. A method of computing effectiveness of an insecticide. Journal of Economic Entomology, vol. 18, no. 2, pp. 265-267. http://dx.doi.org/10.1093/jee/18.2.265a.

AYRES, M. and AYRES JUNIOR, M., AYRES, D.L. and SANTOS, A.A.S., 2007. Bioestat: aplicações estatísticas nas áreas das ciências biomédicas. Versão 5.0. Belém: Sociedade Civil Mamirauá. 324 p.

BARBOSA-NEGRISOLI, C.R.C., GARCIA, M.S., DOLINSKI, C., NEGRISOLI JUNIOR, A.S., BERNARDI, D. and NAVA, D.E., 2009. Efficacy of indigenous entomopathogenic nematodes (Rhabditida: Heterorhabditidae, Steinernematidae), from Rio Grande do Sul, Brazil, against Anastrepha fraterculus (Wied.) (Diptera: Tephritidae) in peach orchards. Journal of Invertebrate Pathology, vol. 102, no. 1, pp. 6-13. http://dx.doi.org/10.1016/j. jip.2009.05.005. PMid:19460384.

BEAVERS, J.B., MCCOY, C.W. and KAPLAN, D.T., 1983. Natural enemies of subterranean Diaprepes abbreviates (Coleoptera:
Curculionidae) larvae in Florida. Environent Entomolology, vol. 12, no. 3, pp. 840-843. http://dx.doi.org/10.1093/ee/12.3.840.

BOFF, M.I.C., WIEGERS, G.L. and SMITS, P.H., 2000. Influences of host size and host species on the infectivity and development of Heterorhabditis megidis (strain NLH-E87.3). BioControl, vol. 45, no. 4, pp. 469-482. http://dx.doi.org/10.1023/A:1026560208285.

CAMPBELL, J.F., LEWIS, E., YODER, F. and GAUGLER, R., 1995. Entomopathogenic nematode (Heterorhabditidae and Steinernematitidae) seasonal population dynamics and impact on insect populations in turfgrass. Biological Control, vol. 5, no. 4, pp. 598-606. http://dx.doi.org/10.1006/bcon.1995.1071.

FLOYD, R., ABEBE, E., PAPERT, A. and BLAXTER, M., 2002. Molecular barcodes for soil nematode identification. Molecular Ecology, vol. 11, no. 4, pp. 839-850. http://dx.doi.org/10.1046/j.1365294X.2002.01485.x. PMid:11972769.

GLAZER, I., KOZODOI, E., SALAME, L. and NESTEL, D., 1996. Spatial and temporal occurrence of natural populations of Heterorhabditis spp. (Nematoda: Rhabditida) in a semiarid region. Biological Control, vol. 6, no. 1, pp. 130-136. http://dx.doi. org/10.1006/bcon.1996.0016.

GREWAL, P.S., GREWAL, S.K., MALIK, V.S. and KLEIN, M.G., 2002. Differences in susceptibility of introduced and native white grub species to entomopathogenic nematodes from various geographic localities. Biological Control, vol. 24, no. 3, pp. 230237. http://dx.doi.org/10.1016/S1049-9644(02)00025-7.

HOY, C.W., GREWAL, P.S., LAWRENCE, J.L., JAGDALE, G. and ACOSTA, N., 2008. Canonical correspondence analysis demonstrates unique soil conditions for entomopathogenic nematode species compared with other free-living nematode species. Biological Control, vol. 46, no. 3, pp. 371-379. http://dx.doi.org/10.1016/j. biocontrol.2008.06.001.

KAYA, H.K., 1990. Soil ecology. In: R. GAUGLER and H.K. KAYA, eds. Entomopathogenic nematodes in biological control. Boca Raton: CRC Press, pp. 93-116.

KLEIN, M.G., 1990. Efficacy against soil-inhabiting insect pests. In: R. GAUGLER and H.K. KAYA, eds. Entomopathogenic nematodes in biological control. Boca Raton: CRC Press, pp. 195-211.

LEZAMA-GUTIÉRREZ, R., MOLINA-OCHOA, J., PESCADORRUBIO, A., GALINDO-VELASCO, E., ÁNGEL-SAHAGÚN, C.A., MICHEL-ACEVES, A.C. and GONZÁLEZ-REYES, E., 2006. Efficacy of Steinernematid nematodes (Rhabditida: Steinernematidae) on the suppression of Anastrepha ludens (Diptera: Tephritidae) larvae in soil of differing textures: laboratory and field trials. Journal of Agricultural and Urban Entomology, vol. 23, no. 1, pp. 41-49.

MARSARO JÚNIOR, A.L., DEUS, E.G., RONCHI-TELES, B., ADAIME, R. and SILVA JÚNIOR, R.J., 2013. Species of Anastrepha (Diptera: Tephritidae) captured in a guava orchard (Psidium guajava L., Myrtaceae) in Boa Vista, Roraima, Brazil. Brazilian Journal of Biology $=$ Revista Brasileira de Biologia, vol. 73, no. 4, pp. 879-886. http://dx.doi.org/10.1590/S1519-69842013000400026. PMid:24789406.

MCGRAW, A. and KOPPENHÖFER, A.M., 2009. Population dynamics and interactions between endemic entomopathogenic nematodes and annual bluegrass weevil populations in golf course turfgrass. Applied Soil Ecology, vol. 41, no. 1, pp. 77-89. http:// dx.doi.org/10.1016/j.apsoil.2008.09.002.

MEJIA-TORRES, M.C. and SÁENZ, A., 2013. Ecological characterisation of the Colombian entomopathogenic nematode 
Heterorhabditis sp. SL0708. Brazilian Journal of Biology $=$ Revista Brasileira de Biologia, vol. 73, no. 2, pp. 239-243. http:// dx.doi.org/10.1590/S1519-69842013000200003. PMid:23917550.

NASCIMENTO, A.S., CARVALHO, R.S. and MALAVASI, A., 2000. Monitoramento populacional. In: A. MALAVASI and R.A. ZUCCHI, eds. Moscas-das-frutas de importância econômica no Brasil: conhecimento básico e aplicado. Ribeirão Preto: Holos Editora, pp. 110-112.

NATIONAL CENTER FOR BIOTECHNOLOGY INFORMATION - NCBI, 2015 [viewed 2 February 2015]. BLAST: basic local alignment search tool [online]. Available from: https://blast.ncbi. nlm.nih.gov/Blast.cgi?PAGE_TYPE=BlastSearch

PARK, H.W., KIM, Y.O., HA, J., YOUN, S.H., KIM, H.H., BILGRAMI, A.L. and SHIN, C.S., 2011. Effects of associated bacteria on the pathogenicity and reproduction of the insect-parasitic nematode Rhabditis blumi (Nematoda: Rhabditida). Canadian Journal of Microbiology, vol. 57, no. 9, pp. 750-758. http://dx.doi. org/10.1139/w11-067. PMid:21867444.

POINAR-JUNIOR, G.O., 1990. Taxonomy and biology of Steinernematidae and Heterorhabditidae. In: R. GAUGLER and H.K. KAYA, eds. Entomopathogenic nematodes in biological control. Boca Raton: CRC Press, pp. 23-61.

PUZA, F. and MRACEK, Z., 2005. Seasonal dynamics of entomopathogenic nematodes of the genera Steinernema and Heterorhabditis as a response to abiotic factors and abundance of insect hosts. Journal of Invertebrate Pathology, vol. 89, no. 2, pp. 116-122. http://dx.doi.org/10.1016/j.jip.2005.04.001. PMid:15893761.

R DEVELOPMENT CORE TEAM, 2008 [accessed 20 November 2014]. $R$ : a language and environment for statistical computing [software]. Vienna: R Foundation for Statistical Computing. Available from: http://www.R-project.org

RIO, R.V. and CAMERON, E.A., 2000. Heterorhabditis bacteriophora: seasonal dynamics and distribution in a stand of sugar maple, Acer saccharum. Journal of Invertebrate Pathology, vol. 75, no. 1, pp. 36-40. http://dx.doi.org/10.1006/jipa.1999.4887. PMid:10631055.

RODRIGUES-TRENTINI, F., 1996. Mecanismos de defesa e controle de Anastrepha fraterculus (Wiedemann, 1830) (Diptera: Tephritidae) expostas a nematoides entomopatogenicos. Curitiba: Universidade Federal do Paraná, 73 p. Dissertação de Mestrado em Ciências Biológicas.

ROHDE, C.R., MOINO-JUNIOR, A., CARVALHO, F.D. and SILVA, M.A.T., 2012. Selection of entomopathogenic nematodes for the control of the fruit fly Ceratitis capitata (Diptera: Tephritidae). Revista Brasileira de Ciências Agrárias, vol. 7, (suppl.), pp. 797802. http://dx.doi.org/10.5039/agraria.v7isa2217.

SALLES, L.A., 2000. Biologia e ciclo de vida de Anastrepha fraterculus (Wied.). In: A. MALAVASI and R.A. ZUCCHI, eds. Moscas-das-frutas de importância econômica no Brasil: conhecimento básico e aplicado. Ribeirão Preto: Holos Editora, pp. 81-91.

SEREPA, M.H. and GRAY, V.M., 2014. Draft whole-genome sequence of Serratia marcescens strain MCB, associated with Oscheius sp. MCB (Nematoda: Rhabditidae) isolated from South Africa. Genome Announcements, vol. 2, no. 5, pp. 911-914. http:// dx.doi.org/10.1128/genomeA.00911-14. PMid:25237022.

SMART, G.C. and NGUYEN, K.B., 1994. Rhabditis (Oscheius) pheropsophi $\mathrm{n}$. sp. (Rhabditida: Rhabditidae). Journal of Nematology, vol. 22, no. 1, pp. 19-24. PMid:19279864.

SOUZA-FILHO, M.F., RAGA, A., AZEVEDO-FILHO, J.A., STRIKIS, P.C., GUIMARÃES, J.A. and ZUCCHI, R.A., 2009.
Diversity and seasonality of fruit flies (Diptera: Tephritidae and Lonchaeidae) and their parasitoids (Hymenoptera: Braconidae and Figitidae) in orchards of guava, loquat and peach. Brazilian Journal of Biology $=$ Revista Brasileira de Biologia, vol. 69, no. 1, pp. 31-40. http://dx.doi.org/10.1590/S1519-69842009000100004. PMid:19347143.

STOCK, S.P., 2005. Insect-parasitic nematodes: form lab curiosities to model organisms. Journal of Invertebrate Pathology, vol. 89, no. 5, pp. 57-66. http://dx.doi.org/10.1016/j.jip.2005.02.011. PMid:16039306.

STOCK, S.P., CAICEDO, A.M., CALATAYUD, P.A., 2005. Rhabditis (Oscheius) colombiana n. sp. (Nematoda: Rhabditidae), a necromenic associate of the subterranean burrower bug Cyrtomenus bergi (Hemiptera: Cydnidae) from the Cauca Valley, Colombia. Nematology, vol. 7, no. 3, pp. 363-373. http://dx.doi. org/10.1163/156854105774355590.

SUBBOTIN, S.A., VIERSTRAETE, A., DE-LEY, P., ROWE, J., WAEYENBERGE, L., MOENS, M. and VANFLETEREN, J.R., 2001. Phylogenetic relationships within the cyst-forming nematodes (Nematoda: Heteroderidae) based on analysis of sequences from the ITS regions of ribosomal DNA. Molecular Phylogenetics and Evolution, vol. 21, no. 1, pp. 1-16. http://dx.doi.org/10.1006/ mpev.2001.0998. PMid:11603932.

TOLEDO, J., SÁNCHEZ, J.E., WILLIAMS, T., GÓMEZ, A., MONTOYA, P. and IBARRA, J.E., 2014. Effect of soil moisture on the persistence and efficacy of Heterorhabditis bacteriophora (Rhabditida: Heterorhabditidae) against Anastrepha ludens (Diptera: Tephritidae) larvae. The Florida Entomologist, vol. 97, no. 2, pp. 528-533. http://dx.doi.org/10.1653/024.097.0225.

TORRES-BARRAGAN, A., SUAZO, A., BUHLERC, W.G. and CARDOZA, Y.J., 2011. Studies on the entomophathogenicity and bacterial associates of the nematode Oscheius carolinensis. Biological Control, vol. 59, no. 2, pp. 123-129. http://dx.doi.org/10.1016/j. biocontrol.2011.05.020.

VOSS, M., ANDALÓ, V., NEGRISOLI-JUNIOR, A.S. and BARBOSA-NEGRISOLI, C.R., 2009 [viewed 21 May 2013]. Manual de técnicas laboratoriais para obtenção, manutenção e caracterização de nematoides entomopatogênicos [online]. Passo Fundo: Embrapa Trigo. 44 p. Available from: $<$ http://www.infoteca. cnptia.embrapa.br/handle/doc/853176

WALDER, J.M.M., MORELLI, R., COSTA, K.Z., FAGGIONI, K.M., SANCHES, P.A., PARANHOS, B.A.J., BENTO, J.M.S. and COSTA, M.L.Z., 2014. Large scale artificial rearing of Anastrepha sp.1 aff. fraterculus (Diptera: Tephritidae) in Brazil. Scientia Agricola, vol. 71, no. 4, pp. 281-286. http://dx.doi. org/10.1590/0103-9016-2013-233.

YE, A., TORRES-BARRAGAN, A. and CARDOZA, Y.J., 2011. Oscheius carolinensis $\mathrm{n}$. sp. (Nematoda: Rhabditidae), a potencial entomopathogenic nematode from vermicompost. Nematology, vol. 12, no. 1, pp. 121-135. http://dx.doi.org/10.1163/156854109X458464.

ZUCCHI, R., 2000a. Espécies de Anastrepha, sinonímias, plantas hospedeiras e parasitóides. In: A. MALAVASI and R.A. ZUCCHI, eds. Moscas-das-frutas de importância econômica no Brasil: conhecimento básico e aplicado. Ribeirão Preto: Holos Editora, pp. 41-48.

ZUCCHI, R., 2000b. Taxonomia. In: A. MALAVASI and R.A. ZUCCHI, eds. Moscas-das-frutas de importância econômica no Brasil: conhecimento básico e aplicado. Ribeirão Preto: Holos Editora, pp. 13-24. 